The marriage of two albinos is extremely rare. Froggatt (1960) in his exhaustive study of albinism in Northern Ireland did not find any instance of such a marriage. He did list several such matings from the literature but commented that they were mostly on hearsay evidence. He considered only two albino $\times$ albino matings as well substantiated; namely families reported by Trevor-Roper (1952) and by Bhende (1952). Trevor-Roper (1963) reinvestigated the family he described in 1952. This albino couple had four normally pigmented children. There was no ground to doubt the paternity, and both parents and two of the children were blood typed, and found compatible. This is the only published, well-substantiated family of an albino couple having unaffected children. The findings of different biochemical defects in albinos from several families as demonstrated by Witkop, Van Scott, and Jacoby (1963) may be explained by different alleles, or different loci. Witkop, according to a personal communication to McKusick (1966), tested the parents of the family reported by Trevor-Roper and was able to show a biochemical difference between the albinism of the father and that of the mother. However, the albino couple reported by Bhende (1952) had four children all of whom were affected.

We wish to report a second albino $\times$ albino mating with all children albinos.

\section{Family Data}

The family came to our attention when examining the three children in the low vision clinic of the ophthalmological department (III.1, III.2, III.3, Fig. 1 and 2). The family history was obtained from the parents (II.7, II.8) who were both albino. The father (II.7) was a Jew born in 1921 in Egypt. His father (I.1) was born in Syria and his mother (I.2), though born in Egypt, was of Moroccan origin; I.1 and I.2 were not related. I.1 and I. 2 were deceased at the time of the present investiga-

Received 25 November 1969. tion, but a photograph showed them to be normally pigmented and they were reported normal by their son (II.7). Two of the father's sibs II.1 and II.4 died as adults. II.4, an albino, was reported to have died of epilepsy at the age of 19 . The 33-year-old albino sister II.6 was examined by us. Apart from his two affected sibs, the father (II.7) vaguely recollected a cousin who may have been albino, but did not remember any details regarding the more distant family. The mother (II.8) was a Jewess born in 1923 in Libya, and her family had lived in that country for many generations. Her parents, I.3 and I.4, were uncle and niece. A photograph of I.3 and I.4 showed them to be normally pigmented, and they were reported normal by their daughter (II.8). Two sibs of II.8, namely II.17 and II. 18 had died in infancy, while the remaining 8 sibs of the mother were adult and alive at the time of the present investigation. Two of them II.13, and II.14, aged 28 and 24, respectively, are albino. II.8 told us of some first cousins once removed who were albinos but she could not remember details.

The couple II.7 and II.8 met in Israel in 1956 through an arranged match and married at ages 35 and 33, respectively. Their three albino children, III.1, III.2, and III.3, are at present 12,11 , and 9 years old.

\section{Clinical Findings}

Both parents and their three children (see Fig. 2) are typical albinos. They have completely white hair and a diffuse absence of normal pigmentation in the skin which is not patterned in any way. The ophthalmological findings of the whole family can be summarized as follows: low visual acuity, never better than $6 / 30$ in the good eye after correction; light blue translucent irises; coarse horizontal nystagmus, and photophobia. II.7 has a right exotropia; II.8 and III.3 an alternating esotropia. The typical albinotic fundus pattern was present in all of them.

\section{Discussion}

The findings of a homozygous albino $\times$ albino mating with normal offspring could be accepted as a proof that the two parents were homozygous for 153 

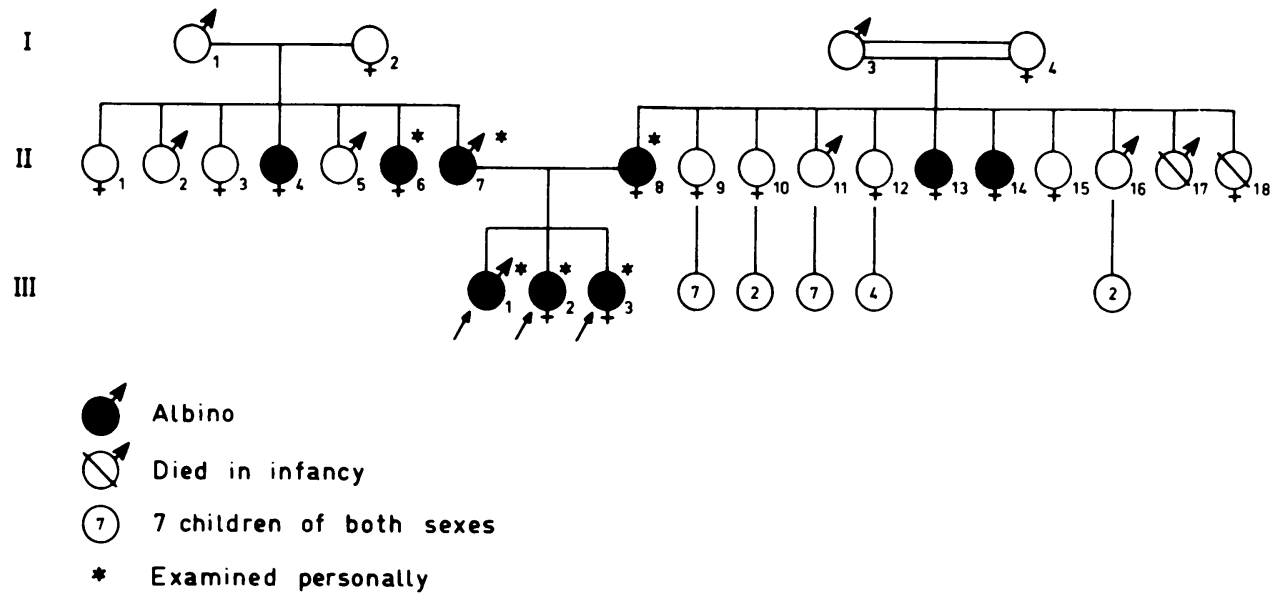

Fig. 1. Pedigree of family.

genes at different loci only if extramarital origin of the children could be absolutely excluded. The finding of albino offspring from an albino $\times$ albino mating, as in the above reported family, proves that the unrelated parents were homozygous at the same locus.

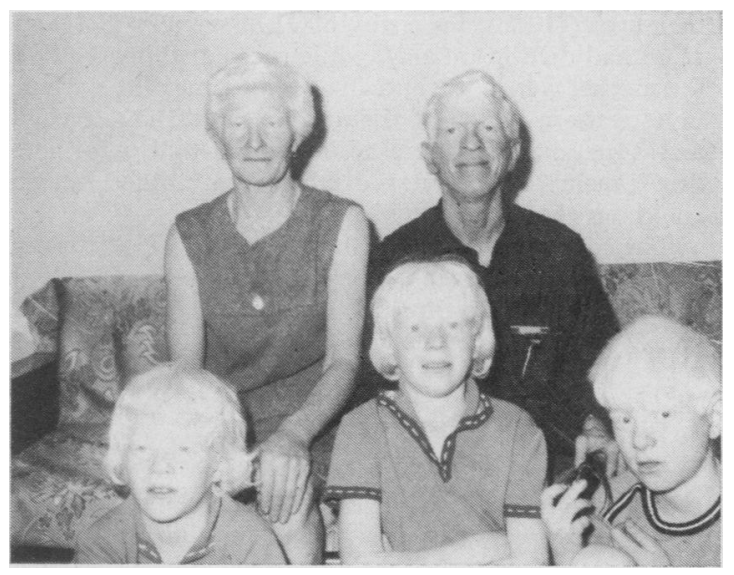

FIG. 2. From left to right: upper row parents II.8, II.7. Lower row children III.3, III.2, III.1.

The concept of more than one segregating mutant at a single locus for albinism was discussed by Froggatt (1960), and he decided that this was the most satisfactory hypothesis. Genetic evidence shows that at least two different loci may produce recessive albinism. This is the conclusion following from the family of Trevor-Roper $(1952,1963)$. The classical calculations of gene frequencies on the assumption of a single locus are thus certainly unjustified. The number of loci involved and the frequency of mutants at each locus is unknown. $\vec{c}$ Though the marriage of two albinos is rare, it may indeed be more frequent than the random chance because of the opportunity of albinos to meet at $\vec{\theta}$ institutions where people with low vision meet, e.g. low vision clinics, centres for partially sighted, and 0 professional training schools for the blind. On the other hand the widespread knowledge of the recessive transmission of the defect may discourage such practice.

The present couple have three affected children. The parents though originating from different Jewish communities were thus affected at the same locus. Careful collection of similar pedigrees over the years may indicate if two or more loci are involved and may lead to more accurate estimates of their frequencies.

\section{Summary}

A marriage of two autosomal recessive albinos that produced three albino children and no normal 0 child is reported. The same locus must have been involved in both parents.

\section{REFERENCES}

Bhende, Y. M. (1952). Malignant amelanotic melanoma in the skin of an albino. Indian fournal of Medical Sciences, 6, 755- N 759.

Froggatt, P. (1960). Albinism in Northern Ireland. Annals of $\omega$ Human Genetics, 24, 213-238.

McKusick, V. A. (1966). Albinism. In Mendelian Inheritance in Man, p. 145. The Johns Hopkins Press, Baltimore.

Trevor-Roper, P. D. (1952). Marriage of two complete albinos with normally pigmented offspring. British fournal of Ophthalmo$\log y, 36,107-108$.

- (1963). Albinism. Proceedings of the Royal Society of Medicine, 56, 21-24.

Witkop, C. J., Van Scott, E. J., and Jacoby, G. A. (1963). Evidence for two forms of autosomal recessive albinism in man. In Proceedings of the Second International Congress of Human Genetics, Q Vol.2, pp. 1064-1066. Edited by L. Gedda. Istituto G. Mende], 